\title{
EXPOSURE OF VENTILATION SYSTEM CLEANING WORKERS TO HARMFUL MICROBIOLOGICAL AGENTS
}

\author{
NARAŻENIE PRACOWNIKÓW KONSERWUJĄCYCH INSTALACJE WENTYLACYJNE \\ NA SZKODLIWE CZYNNIKI MIKROBIOLOGICZNE
}

\author{
Central Institute for Labour Protection - National Research Institute / Centralny Instytut Ochrony Pracy - \\ Państwowy Instytut Badawczy, Warszawa, Poland \\ Laboratory of Biohazard, Department of Chemical, Aerosol and Biological Hazards / Pracownia Zagrożeń Biologicznych, \\ Zakład Zagrożeń Chemicznych, Pyłowych i Biologicznych
}

\begin{abstract}
Background: Regular inspection of the cleanliness of the ventilation systems, as well as their periodic cleaning and disinfection, if necessary, are the main factors of the proper maintenance of each system. Performing maintenance operations on the ventilation system, workers are exposed to risk associated with the exposure to harmful biological agents. The aim of this study was to assess the employees' exposure to bioaerosols during maintenance work on ventilation systems. Material and Methods: Bioaerosol measurements were carried out using a button sampler. The microbial particles were collected on gelatin filters. Settled-dust samples from the inner surface of the air ducts and filter-mat samples were selected for the microbiological analysis. In the collected air, dust and filter samples the concentration of bacteria and fungi were determined. Results: Bacteria and fungi concentrations ranged between $3.6 \times 10^{2}-2.2 \times 10^{4} \mathrm{CFU} / \mathrm{m}^{3}$ and $4.7 \times 10^{2}-4.5 \times 10^{3} \mathrm{CFU} / \mathrm{m}^{3}$ at workplaces where the operations connected with mechanical ventilation cleaning were performed and $2.2 \times 10^{4}-1.2 \times 10^{5} \mathrm{CFU} / \mathrm{m}^{3}$ and $9.8 \times 10^{1}-2.5 \times 10^{2} \mathrm{CFU} / \mathrm{m}^{3}$ at workplaces where filter exchange was performed, respectively. The qualitative analysis of microorganisms isolated from the air in all studied workplaces revealed that the most prevalent bacteria belonged to Bacillus genus. The average concentrations of bacteria and fungi in filter-mat samples were $3.3 \times 10^{3} \mathrm{CFU} / \mathrm{cm}^{2}$ and $1.4 \times 10^{4} \mathrm{CFU} / \mathrm{cm}^{2}$, respectively. In settled-dust samples, average concentrations were $591 \mathrm{CFU} / 100 \mathrm{~cm}^{2}$ and $52 \mathrm{CFU} / 100 \mathrm{~cm}^{2}$, for bacteria and fungi respectively. Conclusions: Workers cleaning ventilation systems are exposed to harmful biological agents classified into risk groups, 1 and 2, according to their level of the risk of infection. The research conducted in the workplace can be the basis of risk assessment related to exposure to harmful biological agents during maintenance work in ventilation. Med Pr 2013;64(5):613-623
\end{abstract}

Key words: bioaerosols, ventilation systems, occupational exposure, harmful biological agents

\section{STRESZCZENIE}

Wprowadzenie: Istotnym elementem właściwej eksploatacji instalacji wentylacyjnych jest regularna kontrola czystości wentylacji oraz jej okresowe czyszczenie i dezynfekcja. W ostatnich latach obserwuje się dynamiczny rozwój firm zajmujących się konserwacją instalacji wentylacyjnych. Pracownicy prowadzący prace konserwacyjne instalacji wentylacyjnej narażeni są na działanie szkodliwych czynników biologicznych. Celem niniejszej pracy było określenie narażenia na te czynniki podczas prac konserwacyjnych w instalacjach wentylacyjnych. Materiał i metody: Pobieranie próbek powietrza wykonano jako pomiar indywidualny za pomocą pobornika guzikowego. Powierzchnię wychwytu stanowiły sterylne filtry żelatynowe. Analizie poddano również próbki pyłu osiadłego z wewnętrznych powierzchni przewodów wentylacyjnych oraz próbki zużytych mat filtracyjnych. Zarówno w próbkach powietrza, pyłu osiadłego, jak i filtrach określano stężenie bakterii i grzybów, a następnie identyfikowano rodzaj lub gatunek wyizolowanych mikroorganizmów. Wyniki: Stężenia aerozolu bakteryjnego i grzybowego mieściły się w zakresie odpowiednio $3,6 \times 10^{2}-2,2 \times 10^{4} \mathrm{jtk} / \mathrm{m}^{3}$ i $4,7 \times 10^{2}-4,5 \times 10^{3} \mathrm{jtk} / \mathrm{m}^{3}$ na stanowiskach pracy, na których wykonywano czynności związane $\mathrm{z}$ mechanicznym czyszczeniem instalacji wentylacyjnych, oraz $2,2 \times 10^{4}-1,2 \times 10^{5} \mathrm{jtk} / \mathrm{m}^{3}$ i $9,8 \times 10^{1}-2,5 \times 10^{2}$ na stanowiskach pracy, na których wymieniano filtry. W powietrzu na wszystkich badanych stanowiskach pracy dominowały bakterie $z$ rodzaju Bacillus. Średnie stężenie mikroorganizmów wyizolowanych z próbek mat filtracyjnych wynosiło dla bakterii: $3,3 \times 10^{3} \mathrm{jtk} / \mathrm{cm}^{2}$, a dla grzybów: $1,4 \times 10^{4} \mathrm{jtk} / \mathrm{cm}^{2}$, natomiast z próbek pyłu osiadłego $-591 \mathrm{jtk} / 100 \mathrm{~cm}^{2}$ dla bakterii i $52 \mathrm{jtk} / 100 \mathrm{~cm}{ }^{2}$ dla grzybów. Wnioski: Pracownicy konserwujący instalacje wentylacyjne są narażeni na kontakt ze szkodliwymi czynnikami biologicznymi z 1. i 2. grupy zagrożenia. Badania przeprowadzone na stanowiskach pracy mogą być podstawą oceny ryzyka zawodowego związanego z narażeniem na szkodliwe czynniki biologiczne podczas prac konserwacyjnych w instalacjach wentylacyjnych. Med. Pr. 2013;64(5):613-623

Słowa kluczowe: bioaerozole, instalacje wentylacyjne, narażenie zawodowe, szkodliwe czynniki biologiczne

This publication is based on the results of the second stage of the multi-annual programme entitled "The improvement of safety and work conditions" financed in the years 2011-2013 within the framework of state services tasks by the Ministry of Labour and Social Policy. Programme Coordinator: Central Institute for Labour Protection - National Research Institute in Poland. Project manager: Małgorzata Gołofit-Szymczak, PhD. 
Corresponding author / Autorka do korespondencji: Małgorzata Gołofit-Szymczak, Laboratory of Biohazard,

Department of Chemical, Aerosol and Biological Hazards, Central Institute for Labour Protection - National Research Institute,

Czerniakowska 16, 00-701 Warszawa, Poland, e-mail: magol@ciop.pl

Received: 2013, September 2, accepted: 2013, November 12

\section{INTRODUCTION}

The function of a ventilation system is to maintain a high quality of air in a building, a specific room or its part. The most important air parameters that can be regulated in a ventilated room are temperature, humidity, airflow velocity and the concentration of biological and chemical pollution.

One of the most-used methods of air treatment is the filtration of outside air on nonwoven filters before its introduction into the rooms. The particles that have managed to pass through the initial filters can settle on the surfaces of devices in ventilation units, on the inside surfaces of the ducts and other elements of the system causing them to be polluted (1-5). In ventilation systems there are usually favourable conditions for the development of harmful biological agents (HBA), mainly bacteria and fungi created due to the presence of surfaces polluted with particles of dust and increased humidity caused by ventilation channels, air filters, thermal insulation installations, noise mufflers, air coolers etc. $(2,6)$.

With an extended period of usage, lack of control regarding the amount of the settled dust and microorganisms, ventilation systems can be a source of unwanted air contamination with pathogenic microbes. Wrong usage and maintenance of ventilation systems (using filters that are not efficient enough, long filter usage, no systematic cleaning and disinfection) can cause additional contamination of rooms because of secondary dusting $(2,7)$. The quality of the air in ventilated rooms is mainly the effect of ventilation ducts that transfer the treated air from the ventilation or airconditioning unit. Some of the pollution deposited on the inside surfaces of ventilation ducts, together with streams of passing air, can spread to the other elements of the system and the rooms served by it.

The requirement to maintain the appropriate air quality is met by a properly-designed, used and managed ventilation system. An important element in an effective ventilation system is a regular ventilation cleanness control and its regular cleaning and possible disinfection. Many legal Acts determine the frequency and methods of conducting an installation inspection and ways of removing pollution from air-conditioning ducts and units that serve rooms with different purposes (5). In recent years, in Poland, we have seen the dynamic development of companies dealing in ventilation system maintenance, which has resulted in a rising number of employees working in those companies. The employees conducting maintenance works (repairs, cleaning, filter replacement) on ventilation systems are exposed to harmful biological agents. Until now this group was not covered by this type of examination in the workplace, which has significant impact on improper work safety management.

The purpose of this research was to determine the level of exposure to harmful microbiological agents during the maintenance works on ventilation systems.

\section{MATERIAL AND METHODS}

\section{Measurement and analysis of bioaerosols}

Research was conducted in the spring-summer season (May-September) in five buildings in the workplaces of maintenance technicians of ventilation systems during the replacement of ventilation filters and during the mechanical cleaning of the ventilation system. Air samples were collected in 6 workplaces in ventilation units during the replacement of filter mats and pocket filters, as well as in 8 workplaces during the mechanical cleaning of ventilation systems. Simultaneously, air samples were collected in rooms where the activities mentioned above were not performed ("background" measurement).

The collection of air samples was performed individually by a filtration method using a button personal inhalable aerosol sampler. During the collection, the measurement devices were fastened on special harness worn by the worker in such a way that the head with the filter was at the same level as the breathing area. The capture surfaces were presterilized gelatin filters. The time of collecting the sample was $30 \mathrm{~min}$ and the airflow velocity was $4 \mathrm{l} / \mathrm{min}$.

In order to determine the number of units forming the colonies for the examined groups of microorganisms, the filters were subject to extraction in sterile water and the obtained solution was put on a Petri dish with the efficient microbiological medium: 
for mesophilic bacteria - trypticase soy agar (TSA) with $5 \%$ of defibrinated sheep blood added (produced by bioMérieux, Marcy-l'Étoile, France),

for Gram-negative bacteria - eosin methylene blue agar (EMB) (produced by bioMérieux, France),

for thermophilic bacteria - 50\% TSA (which means a $50 \%$ concentration of the ingredients) (produced by BTL, Poland),

for fungi - malt-extract agar (MEA) (produced by BTL, Poland).

The conditions of the incubation of microbiological air samples for the examined groups of microorganisms were the following:

mesophilic bacteria, including Gram-negative bacteria -1 day $\left(37^{\circ} \mathrm{C}\right)+3$ days $\left(22^{\circ} \mathrm{C}\right)+3$ days $\left(4^{\circ} \mathrm{C}\right)$, thermophilic bacteria -6 days $\left(55^{\circ} \mathrm{C}\right)$,

fungi -4 days $\left(30^{\circ} \mathrm{C}\right)+4$ days $\left(22^{\circ} \mathrm{C}\right)$.

The concentration of living microorganisms (bacterial and fungal) was expressed as the number of units forming colonies on the microbiological growth medium, $\mathrm{CFU}$, present in $1 \mathrm{~m}^{3}$ of the collected air $\left(\mathrm{CFU} / \mathrm{m}^{3}\right)$. The microorganisms isolated from air samples were identified to the level of genus or species. The identification of the bacteria was conducted on the basis of morphological analysis and using the analytical profile index (API) (produced by bioMérieux, France). The identification of fungal microorganisms was based on the observation of macro- and microscopic characteristics of the colony managed using the available taxonomic keys. For the identification of yeasts, the API AUX yeast-identification kit was used (produced by bioMérieux, France).

\section{Analysis of dust samples settled in the ventilation ducts}

The samples of settled dust were collected from the inside surfaces of the ventilation ducts over an area of $100 \mathrm{~cm}^{2}$ using sterile swabs, included in the transportation kit (produced by FL Medical, Italy). The samples were collected at the end of the air ducts of the ventilation systems. In every examined building, 3 to 5 samples were collected. After collecting the samples, the swabs were put into sterile transport test-tubes $(5 \mathrm{ml})$. The samples of the settled dust were prepared using the plate-dilution technique. The samples with a transport medium were shaken using a laboratory shaker, and afterwards the obtained suspension was put, with the surface method (repeated 3 times), on Petri dishes with the right microbiological medium. The identification of microorganisms was performed analogically as in the case of the analysis of bioaerosol. The results were pre- sented as the CFU values per $1 \mathrm{~cm}^{2}$ of the examined surface $\left(\mathrm{CFU} / \mathrm{cm}^{2}\right)$.

\section{Analysis of the filter-mat samples}

From the filter mats, samples were extracted, each of which had $10 \times 10 \mathrm{~cm}$, and afterwards they were transferred to flasks containing $90 \mathrm{ml} \mathrm{NaCl}(0.85 \%$ concentration). The samples were shaken for 1 hour. For every suspension obtained that way, a series of dilutions were created $\left(10^{-1}-10^{-9}\right)$, which were then put (in 3 repeats), in the amount of $1 \mathrm{ml}$, on Petri dishes filled with a microbiological medium appropriate for every examined group. The identification of microorganisms was conducted analogically as in the case of bioaerosol analysis. The obtained results were counted per $1 \mathrm{~cm}^{2}$ of the examined sample $\left(\mathrm{CFU} / \mathrm{cm}^{2}\right)$.

\section{Statistical analysis}

The obtained measurement data were statistically interpreted on the basis of a single-factor analysis of variance (ANOVA) and post-hoc analysis (Scheffe's test) using the Statistica computer program, version 7.1-2006 (produced by StatSoft, Inc., USA), with statistically-significant values $\mathrm{p}<0.05$.

\section{RESULTS}

\section{Quantitative analysis of bacterial and fungal aerosols}

The values of the concentration of bacterial and fungal aerosols in the air at workplaces and in the outside background obtained using a button personal inhalable aerosol sampler are shown in Table 1.

The quantity analysis of the air samples shows that average concentrations of bacterial and fungal aerosols stay within the range of $3.6 \times 10^{3}-2.3 \times 10^{4} \mathrm{CFU} / \mathrm{m}^{3}$ and $4.8 \times 10^{2}-4.6 \times 10^{3} \mathrm{CFU} / \mathrm{m}^{3}$, respectively, in the workplaces where mechanical cleaning of the ventilation systems was performed and $2.3 \times 10^{4}-1.2 \times 10^{5} \mathrm{CFU} / \mathrm{m}^{3}$ and $2.9-4.6 \times 10^{3}$ in the workplaces where filter replacement was performed. The research showed the existence of statistically-significant differences in the levels of the concentration of microorganisms between particular measurement points (ANOVA: $\mathrm{p}<0.05$ ). The concentration of the bacteria and fungi in the air in the workplaces where the replacement of filter mats and pocket filters was performed was higher by a statistically-significant value compared to the measurement points where mechanical cleaning of the ventilation systems was performed (Scheffe's test: in both cases $\mathrm{p}<0.05$ ). 
Table 1. Bacterial and fungal concentration in the air at the studied workplaces and in background

Tabela 1. Stężenie bakterii i grzybów w powietrzu na badanych stanowiskach pracy oraz w tle

\begin{tabular}{|c|c|c|c|c|c|c|c|}
\hline \multirow{2}{*}{$\begin{array}{c}\text { Sampling station } \\
\text { Stanowisko pomiarowe }\end{array}$} & & \multicolumn{3}{|c|}{$\begin{array}{c}\text { Bacteria }\left[\mathrm{CFU} / \mathrm{m}^{3}\right] \\
\text { Bakterie }\left[\mathrm{jtk} / \mathrm{m}^{3}\right]\end{array}$} & \multicolumn{3}{|c|}{$\begin{array}{l}\text { Fungi }\left[\mathrm{CFU} / \mathrm{m}^{3}\right] \\
\text { Grzyby }\left[\mathrm{jtk} / \mathrm{m}^{3}\right]\end{array}$} \\
\hline & & M & SD & $\begin{array}{c}\text { zakres } \\
\text { range }\end{array}$ & M & $\mathrm{SD}$ & $\begin{array}{c}\text { zakres } \\
\text { range }\end{array}$ \\
\hline \multirow{8}{*}{$\begin{array}{l}\text { Mechanical cleaning of ventilating } \\
\text { systems / Mechaniczne czyszczenie } \\
\text { instalacji wentylacyjnych }\end{array}$} & 1 & $1.3 \times 10^{4}$ & 3778 & $9.6 \times 10^{3}-1.7 \times 10^{4}$ & $3.0 \times 10^{3}$ & 443 & $2.7-3.5 \times 10^{3}$ \\
\hline & 2 & $3.6 \times 10^{3}$ & 1739 & $2.2-5.5 \times 10^{3}$ & $1.2 \times 10^{3}$ & 157 & $1.1-1.4 \times 10^{3}$ \\
\hline & 3 & $5.1 \times 10^{3}$ & 2156 & $2.8-7.0 \times 10^{3}$ & $2.1 \times 10^{3}$ & 424 & $1.8-2.6 \times 10^{3}$ \\
\hline & 4 & $1.2 \times 10^{4}$ & 3123 & $9.0 \times 10^{3}-1.5 \times 10^{4}$ & $1.4 \times 10^{3}$ & 198 & $1.2-1.6 \times 10^{3}$ \\
\hline & 5 & $4.3 \times 10^{3}$ & 2178 & $1.8-6.0 \times 10^{3}$ & $4.8 \times 10^{2}$ & 96 & $4.0-5.8 \times 10^{2}$ \\
\hline & 6 & $3.0 \times 10^{3}$ & 701 & $2.4-3.8 \times 10^{3}$ & $2.7 \times 10^{2}$ & 73 & $2.1-3.5 \times 10^{2}$ \\
\hline & 7 & $1.2 \times 10^{4}$ & 1141 & $1.1-1.4 \times 10^{4}$ & $2.3 \times 10^{3}$ & 357 & $2.0-2.7 \times 10^{3}$ \\
\hline & 8 & $2.3 \times 10^{4}$ & 2367 & $2.8-2.5 \times 10^{4}$ & $4.6 \times 10^{3}$ & 639 & $3.9-5.2 \times 10^{3}$ \\
\hline \multirow{6}{*}{$\begin{array}{l}\text { Replacement of filters / Wymiana } \\
\text { filtrów }\end{array}$} & 9 & $2.6 \times 10^{4}$ & 1916 & $2.4-2.8 \times 10^{4}$ & $3.4 \times 10^{3}$ & 254 & $3.1-3.6 \times 10^{3}$ \\
\hline & 10 & $10.1 \times 10^{5}$ & 2786 & $9.9 \times 10^{4}-1.0 \times 10^{5}$ & $5.1 \times 10^{3}$ & 101 & $5.0-5.2 \times 10^{3}$ \\
\hline & 11 & $2.3 \times 10^{4}$ & 967 & $2.2-2.4 \times 10^{4}$ & $4.6 \times 10^{3}$ & 251 & $4.3-4.8 \times 10^{3}$ \\
\hline & 12 & $2.9 \times 10^{4}$ & 1419 & $2.8-3.1 \times 10^{4}$ & $3.2 \times 10^{3}$ & 112 & $3.1-3.3 \times 10^{3}$ \\
\hline & 13 & $1.2 \times 10^{5}$ & 1041 & $1.2-1.3 \times 10^{5}$ & $4.5 \times 10^{3}$ & 98 & $4.4-4.6 \times 10^{3}$ \\
\hline & 14 & $2.9 \times 10^{4}$ & 797 & $2.9-3.0 \times 10^{4}$ & $2.9 \times 10^{3}$ & 149 & $2.7-3.0 \times 10^{3}$ \\
\hline Background / Tło & 15 & $7.5 \times 10^{2}$ & 59 & $7.0-8.2 \times 10^{2}$ & $0.8 \times 10^{2}$ & 10 & $0.7-0.9 \times 10^{2}$ \\
\hline
\end{tabular}

M - mean / średnia; SD - standard deviation / odchylenie standardowe.

A comparison of the results of the measurement of microorganism concentration for the background and for the workplaces showed that the concentration of bacterial and fungal aerosol in the background was lower by a statistically-significant value than the values of concentration in the workplaces (in both cases $\mathrm{p}<0.01$ ).

\section{Quality analysis of bacterial and fungal aerosols}

The results of the quality analysis of bacterial and fungal aerosols isolated from the air in the examined workplaces are shown in Tables 2 and 3 . In the examined workplaces, there were identified 22 species of bacteria that belong to 12 genera and 12 species of fungi that belong to 8 genera. When it comes to species, the highest numbers of bacteria species belonged to the following genera: Staphylococcus (7 species), Micrococcus (2 species) and Bacillus (7 species), and among the fungi, filamentous fungi of the genus Aspergillus (3 species).

The percentage share of particular groups of bacterial and fungal microorganisms in relation to the whole microbiome isolated from the air samples collected in the examined workplaces is shown in Figure 1.

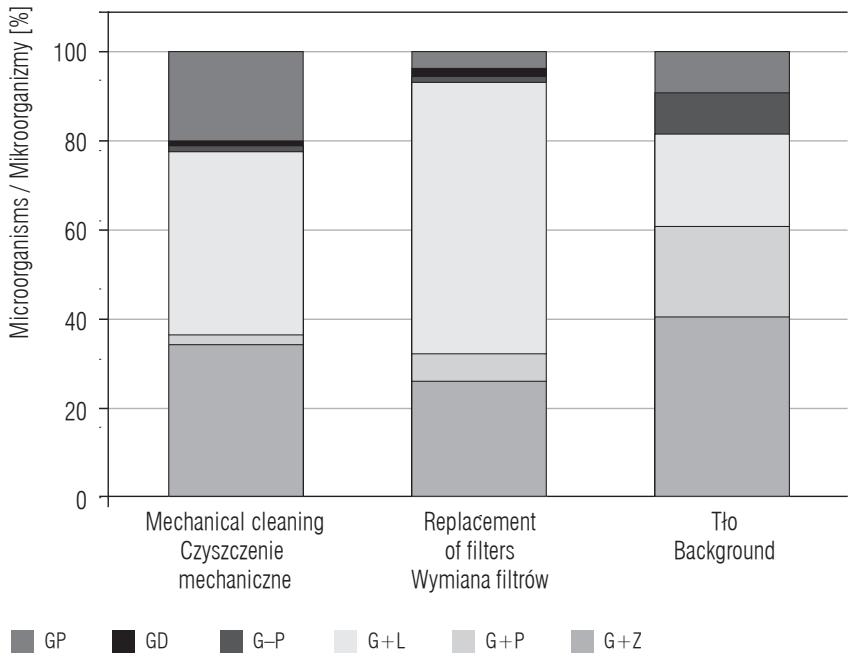

GP - moulds / grzyby pleśniowe.

GD - yeast / grzyby drożdżoidalne.

G-P - Gram-negative rods / pałeczki Gram-ujemne.

$\mathrm{G}+\mathrm{L}$ - Gram-positive bacilli / laseczki Gram-dodatnie.

$\mathrm{G}+\mathrm{P}$ - nonsporing Gram-positive rods / pałeczki Gram-dodatnie niezarodnikujące. $\mathrm{G}+\mathrm{Z}$ - Gram-positive cocci / ziarniaki Gram-dodatnie.

Fig. 1. Microorganisms identified in the air of the studied workplaces

Ryc. 1. Mikroorganizmy w powietrzu badanych stanowisk pracy 
Table 2. Bacteria identified in the air at the studied workplaces and in settled dust

Tabela 2. Bakterie występujące w powietrzu na badanych stanowiskach pracy oraz w pyle osiadłym

\begin{tabular}{|c|c|c|c|c|}
\hline \multirow[b]{2}{*}{$\begin{array}{l}\text { Bacteria } \\
\text { Bakterie }\end{array}$} & \multicolumn{2}{|c|}{$\begin{array}{c}\text { Air } \\
\text { Powietrze }\end{array}$} & \multicolumn{2}{|c|}{$\begin{array}{l}\text { Settled dust } \\
\text { Pył osiadły }\end{array}$} \\
\hline & $\begin{array}{c}\text { mechanical cleaning } \\
\text { of ventilating systems } \\
\text { mechaniczne czyszczenie } \\
\text { instalacji }\end{array}$ & $\begin{array}{l}\text { replacement of filters } \\
\text { wymiana filtrów }\end{array}$ & $\begin{array}{l}\text { filter mats } \\
\text { maty filtracyjne }\end{array}$ & $\begin{array}{l}\text { ventilation ducts } \\
\text { kanały wentylacyjne }\end{array}$ \\
\hline \multicolumn{5}{|l|}{$\begin{array}{l}\text { Gram-positive cocci / Ziarniaki } \\
\text { Gram-dodatnie }\end{array}$} \\
\hline Micrococcus luteus & + & + & - & + \\
\hline Micrococcus roseus & - & - & - & + \\
\hline Micrococcus spp. & + & + & + & + \\
\hline Staphylococcus aureus & + & - & - & - \\
\hline Staphylococcus lentus & + & - & - & - \\
\hline Staphylococcus sciuri & + & + & - & - \\
\hline Staphylococcus xylosus & + & - & + & + \\
\hline \multicolumn{5}{|l|}{$\begin{array}{l}\text { Nonsporing Gram-positive rods / Pałeczki } \\
\text { Gram-dodatnie niezarodnikujące }\end{array}$} \\
\hline Brevibacterium spp. & - & + & - & - \\
\hline Cellulomonas spp. & - & + & - & - \\
\hline Corynebacterium spp.* & + & + & - & - \\
\hline Corynebacterium propinquum & + & - & + & - \\
\hline Bacillus firmus & + & + & + & - \\
\hline Bacillus licheniformis & + & + & + & + \\
\hline Bacillus mycoides & - & + & + & - \\
\hline Bacillus megaterium & + & + & + & + \\
\hline Bacillus spp. & - & + & - & - \\
\hline \multicolumn{5}{|c|}{ Gram-negative rods / Pałeczki Gram-ujemne } \\
\hline Burkholderia cepacia & - & + & - & - \\
\hline Chryseobacterium meningosepticum & + & - & - & - \\
\hline Sphinomonas paucimobilis & + & + & - & - \\
\hline Pseudomonas aeruginosa* & + & + & - & - \\
\hline Pseudomonas oryzihabitans & - & + & - & - \\
\hline \multicolumn{5}{|l|}{$\begin{array}{l}\text { Mesophilic actinomycetes / Mezofilne } \\
\text { promieniowce }\end{array}$} \\
\hline Nocardia spp. & - & - & + & + \\
\hline
\end{tabular}

* Microorganisms classified by the Ordinance of the Minister of Health from April 22nd, 2005, on hazardous biological agents in work environment and health protection of workers exposed occupationally to them into group 2, according to their level of risk of infection / Mikroorganizmy zakwalifikowane do grupy 2. zagrożenia według Rozporządzenia Ministra Zdrowia z dnia 22 kwietnia 2005 r. w sprawie szkodliwych czynników biologicznych dla zdrowia w środowisku pracy oraz ochrony zdrowia pracowników zawodowo narażonych na te czynniki (10). 
Table 3. Fungi identified in the air at the studied workplaces and in settled dust

Tabela 3. Grzyby występujące w powietrzu na badanych stanowiskach pracy oraz w pyle osiadłym

\begin{tabular}{|c|c|c|c|c|}
\hline \multirow[b]{2}{*}{$\begin{array}{l}\text { Fungi } \\
\text { Grzyby }\end{array}$} & \multicolumn{2}{|c|}{$\begin{array}{c}\text { Air } \\
\text { Powietrze }\end{array}$} & \multicolumn{2}{|c|}{$\begin{array}{l}\text { Settled dust } \\
\text { Pył osiadły }\end{array}$} \\
\hline & $\begin{array}{c}\text { mechanical cleaning } \\
\text { of ventilating systems } \\
\text { mechaniczne czyszczenie } \\
\text { instalacji }\end{array}$ & $\begin{array}{l}\text { replacement of filters } \\
\text { wymiana filtrów }\end{array}$ & $\begin{array}{l}\text { filter mats } \\
\text { maty filtracyjne }\end{array}$ & $\begin{array}{l}\text { ventilation ducts } \\
\text { kanały wentylacyjne }\end{array}$ \\
\hline \multicolumn{5}{|c|}{ Filamentous fungi / Grzyby pleśniowe } \\
\hline Acremonium spp. & - & - & - & + \\
\hline Alternaria spp. & - & - & - & + \\
\hline Aspergillus candidus & - & - & + & + \\
\hline Aspergillus flavus & - & - & + & - \\
\hline Aspergillus spp.* & + & + & - & - \\
\hline Cladosporium cladosporioides & + & + & - & - \\
\hline Cladosporium spp. & - & + & - & - \\
\hline Fusarium oxysporum & - & + & - & - \\
\hline Fusarium solani & + & + & + & - \\
\hline Mucor plumbeus & - & + & - & - \\
\hline Mucor spp. & + & + & - & - \\
\hline Penicillium citrinum & - & & + & + \\
\hline Penicillium spp. & + & + & + & + \\
\hline Rhizopus stolonifer & + & + & - & - \\
\hline Scopulariopsis fusca & + & - & - & - \\
\hline Trichoderma spp. & + & + & - & - \\
\hline Trichoderma harzianum & + & - & - & - \\
\hline \multicolumn{5}{|l|}{ Yeasts / Grzyby drożdżoidalne } \\
\hline Candida famata & - & - & + & - \\
\hline Geotrichum spp. & - & - & + & - \\
\hline Geotrichum candidum & - & - & + & - \\
\hline Rhodotorula mucilaginosa & - & - & - & + \\
\hline
\end{tabular}

Abbreviation as in Table 2 / Objaśnienie jak w tabeli 2.

The analysis of the percentage share of the identified microorganisms showed that in the microbiome of air, in all of the examined workplaces, bacteria were dominant (80-95\%), mostly endospore forming Gram-posi- tive rods of the genus Bacillus, including B. cerus, $B$. coagulans, B. firmus, B. licheniformis and B. megaterium which were present in all of the measurement points (42-61\% of the whole microflora). The next in terms 
of frequency of isolation were: Gram-positive cocci (26-34\%) of the following genera: Staphylococcus (7 species), Kocuria (1 species), Micrococcus (1 species), and nonsporing Gram-positive rods (2-7\%) of the following genera: Brevibacterium, Cellulomonas, Microbacterium (1 species in all of the cases) and Corynebacterium (2 species).

The filamentous fungi constituted $5-21 \%$ of the whole microbiome in the examined workplaces. The quality analysis showed that in the air microbiome in all of the examined points the fungi of the following genera were dominant: Aspergillus (A. fumigatus, A. flavus, A. niger, A. ochraceus), Fusarium (F. oxysporum, F. solani), Mucor (M. plumbeus) and Penicillium (P. crustosum, P. glabrum).

\section{Quantity and quality analysis}

\section{of the filter-mat samples}

The values of concentration of the particular groups of microorganisms in the filter-mat samples are shown in Table 4. The average concentration of microorganisms isolated from the filter-mat samples was, for bacteria: $3.3 \times 10^{3} \mathrm{CFU} / \mathrm{cm}^{2}(\mathrm{SD}=343)$ and for fungi: $1.4 \times 10^{4} \mathrm{CFU} / \mathrm{cm}^{2}(\mathrm{SD}=642)$.

The analysis of correlations between the concentration of microorganisms in the filter-mat samples and the concentrations of the examined bioaerosols in the workplaces did not show statistically significant dependencies.

The detailed results of the quality analysis of the bacterial and fungal microflora isolated from the examined filter-mat samples are shown in Tables 2 and 3, and also in Figure 2. The most prolific part of the microorganisms in the filter mats were filamentous fungi (43\%). The next in terms of isolation were Gram-positive cocci (26\%), endospore forming Gram-positive rods (18\%) and nonsporing Gram-positive rods (10\%). The least-numerous groups of microbes were yeasts $(0,5 \%)$ and mesophilic actinobacteria $(2,5 \%)$.

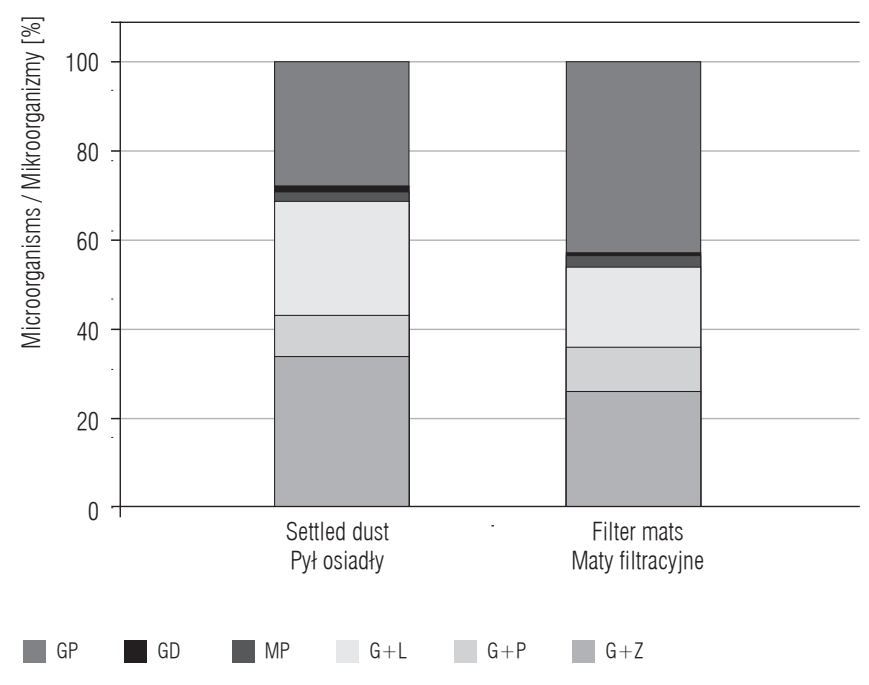

Abbreviations as in Figure 1 / Objaśnienia jak w ryc. 1.

Fig. 2. Microorganisms identified in filter-mat samples and settled-dust samples from the studied ventilation ducts Ryc. 2. Mikroorganizmy w próbkach mat filtracyjnych i pyle osiadłym w badanych kanałach wentylacyjnych

Nine species of bacteria that belong to 12 genera and 13 species of fungi that belong to 6 genera were identified. The most numerous species were the bacteria of the genus Bacillus (4 species) and among fungi the filamentous fungi of the following genera: Aspergillus (5 species) and Penicillium (4 species).

The comparison between the microorganisms isolated from the air in the rooms and those identified in the filter-mat samples showed the presence of analogical species.

\section{Quantity and quality analysis of the settled-dust samples from the ventilation ducts}

The values of concentration of particular microorganism groups in the settled-dust samples from the inside surfaces of the ventilation ducts are shown in Table 4.

Table 4. Bacterial and fungal concentration in filter-mat samples and settled-dust samples from the studied ventilation ducts Tabela 4. Stężenie bakterii i grzybów w próbkach mat filtracyjnych i pyle osiadłym w badanych kanałach wentylacyjnych

\begin{tabular}{|c|c|c|c|c|c|c|}
\hline \multirow{2}{*}{$\begin{array}{l}\text { Sample } \\
\text { Próbka }\end{array}$} & \multicolumn{3}{|c|}{$\begin{array}{c}\text { Bacteria }\left[\mathrm{CFU} / \mathrm{cm}^{2}\right] \\
\text { Bakterie }\left[\mathrm{jtk} / \mathrm{cm}^{2}\right]\end{array}$} & \multicolumn{3}{|c|}{$\begin{array}{l}\text { Fungi }\left[\mathrm{CFU} / \mathrm{cm}^{2}\right] \\
\text { Grzyby }\left[\mathrm{jtk} / \mathrm{cm}^{2}\right]\end{array}$} \\
\hline & M & $\mathrm{SD}$ & $\begin{array}{l}\text { range } \\
\text { zakres }\end{array}$ & M & $\mathrm{SD}$ & $\begin{array}{l}\text { range } \\
\text { zakres }\end{array}$ \\
\hline Filter mats / Maty filtracyjne & $3.3 \times 10^{3}$ & 343 & $3.0-3.6 \times 10^{3}$ & $1.4 \times 10^{4}$ & 642 & $1.3-1.4 \times 10^{4}$ \\
\hline Ventilation ducts / Kanały wentylacyjne & 5.9 & 3.9 & $4.8-7.0$ & 0.5 & 0.4 & $0.4-0.6$ \\
\hline
\end{tabular}

Abbreviations as in Table 1 / Objaśnienia jak w tabeli 1. 
The concentrations of microorganisms isolated from the samples of settled dust from the inside surfaces of ventilation channels in the installations were $5.9 \mathrm{CFU} / \mathrm{cm}^{2}(\mathrm{SD}=3.9)$ for bacteria and $0.5 \mathrm{CFU} / \mathrm{cm}^{2}$ $(\mathrm{SD}=0.4)$ for fungi, respectively. The analysis of the correlations between the concentrations of microorganisms in the dust settled in ventilation channels and the concentration of the examined bioaerosols did not show statistically-significant dependencies.

The percentage share of particular groups of microorganisms in relation to the whole microbiome isolated from the settled-dust samples from the inside surfaces of the ventilation ducts is shown in Figure 2.

The most numerous part of the microorganisms present in the settled-dust were Gram-positive cocci. Their share was $34 \%$ in relation to the whole identified microbiome of the settled dust. The secondmost numerous group of microbes were filamentous fungi - $28 \%$ of the whole microbiome. Endospore forming Gram-positive rods were also quite a numerous group (26\%). The next in terms of isolation were nonsporing Gram-positive rods (9\%). The least-numerous groups of microbes were mesophilic actinobacteria and yeasts ( $2 \%$ and $1 \%$, respectively).

Eight species of bacteria that belong to 6 genera and 14 species of fungi that belong to 5 genera were identified. The most numerous were the bacteria of the genus Micrococcus (2 species) and among the fungi, filamentous fungi of the genera Penicillium and Aspergillus (2 species each).

A comparison of the microorganisms isolated from the air in the rooms with those identified in the dust settled in ventilation ducts showed the presence of analogical species.

\section{DISCUSSION}

The quantitative interpretation of the results of bioaerosol measurement in the work environment is difficult because of the lack of generally acceptable hygiene norms for SCB. The main reason for this situation is the lack of the possibility to establish a strict relationship between the doses of SCB and the health consequences caused by them.

The hygienic assessment of the examined environment of the workers maintaining the ventilation systems was made on the basis of the recommended values of permissible concentration of harmful biological agents in the work environment worked out by the Biological Agents' Expert Group of the Interdepartmental
Commission for Maximum Admissible Concentrations and Intensities for Agents Harmful to Health in the Work Environment (8). Those values have a nature that is close to arbitrary, i.e. they were calculated as a result of cross-sectional environmental research considering the potential harmfulness of certain biological agents $(8,9)$.

The workplaces of the operatives maintaining ventilation systems are not regular public utility rooms, because they can be accessed only by a limited number of workers and the work performed there can be related to the emission of the biological agents into the air. Until now, in Poland, and also in the world, reference values for these kinds of rooms have not been established. In spite of that, using the available suggestions for the permissible concentration of microbes, the authors established that in the workplaces, in ventilation units, during the replacement of filter mats and pocket filters, there was an excess of the recommended reference values for mesophilic bacteria $\left(5000 \mathrm{CFU} / \mathrm{m}^{3}\right)$. The quantitative analysis of the fungal aerosol showed that the obtained concentration values were lower than the recommended permissible limits.

In the rest of the workplaces, during the mechanical cleaning of ventilation systems the obtained average values of bacteria and fungi concentration did not exceed the recommended permissible values.

In order to assess the threat to health caused by microorganisms present in the air in the examined measurement points, a classification based on threat groups has been made. The groups are enumerated in the Ordinance of the Minister of Health of April 22, 2005 on hazardous biological agents in work environment and health protection of workers exposed occupationally to them (10). The qualitative analysis of the bioaerosols in the examined workplaces showed the presence of saprophytic bacterial species that belong to:

the 1st threat group - i.e. the agents that are unlikely to cause human diseases,

the 2nd threat group - can cause human diseases, can be dangerous to the workers, and their diffusion in the human population is unlikely. Usually, there are effective methods of prophylaxis or treatment against them (they were microorganisms of the genus Corynebacterium and the species Pseudomonas aeruginosa).

The species of the genus Corynebacterium are very widespread microbes in the environment, as they are part of human skin and mucosa microflora. Corynebacterium diphtheriae is a pathogenic species for humans, 
but this microorganism was not isolated from the collected samples. Coccobacillus Pseudomonas aeruginosa can cause dangerous lung and urinary system infections. As a Gram-negative bacteria, it releases bacterial endotoxins from its cells. They are pro-inflammatory lipopolysaccharides that negatively influence the respiratory system when highly concentrated. Moreover, Pseudomonas aeruginosa can produce strong A exotoxins and enterotoxins $(11,12)$. The bacteria classified as the 2 nd threat group were rarely isolated from the air in the examined workplaces. The workers maintaining ventilation systems can then be only rarely exposed to the direct contact with that kind of biological agents posing occupational health risks.

In the air, in all of the examined workplaces of the workers maintaining ventilation systems, the same groups of microbes were dominant, i.e. Gram-positive cocci of the following genera: Staphylococcus and Micrococcus, endospore forming rods from the Bacillus genus and filamentous fungi. The species of the genera Staphylococcus and Micrococcus are part of a permanent or transitional human microflora which additionally, with the presence of their possible source (i.e. the workers maintaining the installations), cause a definite dominance over the remaining ingredients of the microbiome.

Determined in the workplaces, bacteria of the genus Bacillus are microbes of environmental origin that usually populate soil and plants. They usually present no threat to humans and they are transferred to the ventilation systems with the atmospheric air. It is also important to point out that the bacteria of the Bacillus genus are capable of creating endospores that make it possible for them to survive in adverse environmental conditions for a long time. For example, the endospore forming bacteria are more resistant than the other groups to the effects of detergents (13).

Among the fungi, only one species, Aspergillus fumigatus, has been classified to the 2 nd threat group. Moreover, the presence of microbes of the genus Penicillium has been noted, of which only one species (Penicillium marneffei) is included in the 2 nd threat group.

It should be emphasised that filamentous fungi appearing in the air even at low concentrations can cause many adverse health effects, including allergic diseases, bronchial asthma, allergic alveolitis, skin allergies and irritation. The literature data shows that filamentous fungi, mainly Aspergillus (A. candidus, A. flavus, A. fumigatus), Cladosporium and Penicillium can pose a specific threat to human health (14-17). They are (along with the species of the genera Alternaria, Trichoderma and Mucor) the most common cause of allergies to filamentous fungi (18). The occurrence and development of filamentous fungi are associated with the release of allergens, mycotoxins, volatile organic compounds and glucans into the environment.

Fungi allergens are the major cause of atopic diseases (19). Contact with filamentous fungi can cause allergic reactions like asthma, conjunctivitis, hay fever and allergic alveolitis. Mycotoxins penetrating into the human body by ingestion can be toxic, carcinogenic, teratogenic, mutagenic, immunosuppressive or immunotoxic (20-22). Aspergillus fumigatus is also characterised by a strong infectious influence (e.g., it can cause pulmonary aspergillosis) (23-25).

The conducted microbiological quantitative analysis of the filter-mat samples showed that the concentration of living bacteria and fungi was, respectively, $3.3 \times 10^{3} \mathrm{CFU} / \mathrm{m}^{2}$ and $1.3 \times 10^{4} \mathrm{CFU} / \mathrm{m}^{2}$. However, in the case of the dust settled on the inner surfaces of ventilation ducts the concentration of living microorganisms was lower and did not exceed $0.6 \times 10^{1} \mathrm{CFU} / \mathrm{m}^{2}$. The resulting microorganism concentration values were similar to those observed by other investigators in this type of samples (26).

The conducted qualitative analysis of the filter samples and the settled-dust samples from the inside surfaces of the ventilation system showed a similar composition of species to the one observed in the air. The dominant group of microorganisms are bacteria of the genus Micrococcus and Bacillus and filamentous fungi, including Aspergillus and Penicillium. The obtained results confirm the data in the literature, where there are numerous works characterising the microbial contamination of ventilation systems. Their analysis shows that the most commonly-isolated bacteria include species of Bacillus (B. cereus, B. pumilus), Micrococcus (M. luteus, M. roseus), Staphylococus (S. epidermidis, S. saprophyticus, S. hominis, S. capitis), Pseudomonas, Flavobacterium and Acinetobacter, and among the fungi Penicillium (P. expansum, $P$. chrysogenum, $P$. commune, $P$. citrinum), Aspergillus (A. fumigatus, A. flavus), Acremonium, Cladosporium, Alterneria (A. alternata, A. tenuissiuma) and Fusarium (F. proliferatum) (2,3,27-29).

\section{CONCLUSIONS}

1. The results of the study indicate that employees maintaining ventilation systems are exposed to harmful biological agents. 
2. The quantitative analysis of bioaerosol in all of the workplaces showed that the obtained values of bacterial aerosol concentrations during the replacement of filter mats and pocket filters are higher than the recommended limit values for mesophilic bacteria.

3. In workplaces, during the mechanical cleaning of the ventilation system, no excessive values for concentrations of bacteria and fungi were observed.

4. The quantitative and qualitative analysis of air microflora in the designated workplaces allowed us to determine the presence of 4 genera and/or species of bacteria and fungi belonging to the 2nd risk group.

5. The research conducted in the workplace can be the basis of risk assessment associated with exposure to biological agents during maintenance work in ventilation.

\section{REFERENCES}

1. Brosseau LM, Vesley D, Kuehn TH, Melson J, Han HS. Methods and criteria for cleaning contaminated ducts and air-handling equipment. ASHRAE Trans. 2000;106:188-9.

2. Charkowska A. [Contamination in air conditioning systems and methods for its removal]. Gdańsk: IPPU MASTA; 2003. Polish.

3. Charkowska A, Bogdan A. [Ventilation and air conditioning - methods of cleaning and disinfection]. Bezp Pr. 2008;10:16-7. Polish.

4. Zuraimi MS. Is ventilation duct clearing useful? A review of scientific evidence. Indoor Air. 2010;20:445-57.

5. Gołofit-Szymczak M, Górny R, Ławniczek-Wałczyk A. [Exposure of ventilation system cleaning workers to harmful biological and chemical agents]. Med Pr. 2012;63(6):711-22. Polish.

6. Chang JCS, Foarde KK, VanOsdell DW. Assessment of fungal (Penicillium chrysogenum) growth of three HVAC duct materials. Environ Int. 1996;22:425-31.

7. Noris F, Siegel JA, Kinney KA. Evaluation of HVAC filters as a sampling mechanism for indoor microbial communities. Atmos Environ. 2011;45:338-46, http://dx.doi.org/10.1016/j.atmosenv.2010.10.017.

8. Górny RL. [Biological aerosols - The role of hygienic standards in environmental protection and health]. Med Środ. 2010;13:41-51. Polish.

9. Górny RL, Cyprowski M, Ławniczek-Wałczyk A, Gołofit-Szymczak M, Zapór L. Biohazards in the indoor environment - A role for threshold limit values in exposure assessment. In: Dudzińska MR, editor. Management of indoor air quality. London: Taylor \& Francis Group; 2011, p. 1-20, http://dx.doi.org/10.1201/b11336-2.
10. [Ordinance of the Minister of Health from April 22nd, 2005 , on hazardous biological agents in work environment and health protection of workers exposed occupationally to them]. Journal of Laws of 2005 no. 81, item 716. Polish.

11. Dutkiewicz J. Bacteria and fungi in organic dust as potential health hazard. Ann Agric Environ Med. 1997;4:11-6.

12. Kędzierska J, Doleżal M, Kachlik P. [Assessment of drugresistant Gram-negative bacilli isolated from clinical material]. Med Dosw. Mikrobiol. 1999;51:113-22.

13. Kotełko K, Sedlaczek L, Lachowicz TM. [Biology of bacteria]. Warszawa: PWN; 1984. Polish.

14. Giulio M, Grande R, Campli E, Bartolomeo S, Cellini L. Indoor air quality in university environments. Environ Monit Assess. 2010;170:509-17, http://dx.doi.org/10.1007/ s10661-009-1252-7.

15. Khan AAH, Karuppayil SM, Manoharachary C, Kunwar IK, Waghray S. Isolation, identification and testing for allegenicity of fungi from air-conditioned indoor environments. Aerobiologia. 2009;25:119-23, http://dx.doi. org/10.1007/s10453-009-9114-x.

16. Holme J, Hägerhed-Engman L, Mattsson J, Sundell C, Bornehag G. Culturable mold in indoor air and its association with moisture-related problems and asthma and allergy among Swedish children. Indoor Air. 2010;20:329-40, http://dx.doi.org/10.1111/j.1600-0668.2010.00658.x.

17. Jones R, Recer GM, Hwang SA, Lin S. Association between indoor mold and asthma among children in Buffalo, New York. Indoor Air. 2011;21:156-64, http://dx.doi.org/10.1111/j.1600-0668.2010.00692.x.

18. Obtułowicz K [red.]. [The practical allergology]. Warszawa: Wyd. Lekarskie PZWL; 2001. Polish.

19. Kurup VP, Shen HD, Vijay H. Immunobiology of fungal allergens. Int Arch Allergy Immunol. 2001;129:181-8, http://dx.doi.org/10.1159/000066780.

20. Gołofit-Szymczak M. [Assessment of exposure to bacterial and fungal aerosols at workplaces in office buildings, with a special emphasis on the ventilation system] [dissertation]. Warszawa: CIOP-PIB; 2012. Polish.

21. Dutkiewicz J, Jabłoński L. [The occupational biological harmful factors]. Warszawa: PZWL; 1989. Polish.

22. Lacey J, Dutkiewicz J. Bioaerosols and occupational lung disease. J Aerosol Sci. 1994;25:1371-404, http://dx.doi.org/10.1016/0021-8502(94)90215-1.

23. Samson RA, Hoekstra ES, Frisvad JC. Introduction to food- and airborne fungi. 7th edition. Utrecht: Centraalbureau voor Schimmelcultures; 2004.

24. Terho EO, Husman K, Kotimaa M, Sjöblom T. Extrinsic allergic alveolitis in a sawmill worker: A case report. Scand J Work Environ Health. 1980;6:153-7, http://dx.doi.org/10.5271/sjweh.2627. 
25. Lacey J, Crook B. Review: Fungal and actinomycete spores as pollutants of the workplace and occupational allergens. Ann Occup Hyg. 1988;32:515-33.

26. Brosseau LM, Vesley D, Kuehn T, Melson J, Han HS. Duct Cleaning: A review of associated health effects and results of company and expert surveys. ASHRAE Transactions. 2000;106:180-7.
27. Gołofit-Szymczak M, Górny RL. Bacterial and fungal aerosols in air-conditioned office buildings in Warsaw, Poland - The winter season. JOSE. 2010;16:465-76.

28. Gołofit-Szymczak M, Skowroń J. [Microbiological hazards in offices]. Bezp Pr. 2005;3:29-35. Polish.

29. Skowroń J, Gołofit-Szymczak M. [Microbiological air pollution in the working environment - sources, types and identification]. Bromat Chem Toksykol. 2004;37:91-8. 